\title{
IMPLEMENTASI HEURISTIC PROBLEM SOLVING DALAM MENYELESAIKAN SOAL CERITA UNTUK MENINGKATKAN PRESTASI DAN SIKAP MATEMATIKA
}

\author{
IMPLEMENTATION OF HEURISTIC PROBLEM SOLVING \\ THE PROBLEM SOLVING MATH STORIES TO IMPROVE ACHIEVEMENT \\ AND ATTITUDE TOWARD MATH
}

\author{
Dian Kristiana, Wardan Suyanto \\ FKIP Universitas Muhammadiyah Ponorogo, Universitas Negeri Yogyakarta \\ dianrespati@ymail.com,wardansuyanto@uny.ac.id
}

\begin{abstract}
Abstrak
Penelitian ini bertujuan untuk meningkatkan prestasi belajar dan sikap siswa terhadap matematika melalui heuristic problem solving dalam menyelesaikan soal cerita matematika. Penelitian ini adalah Penelitian Tindakan Kelas kolaboratif dengan guru matematika kelas IV SD sebagai kolaborator pelaksana tindakan. Teknik pengumpulan data meliputi tes prestasi belajar, angket sikap siswa terhadap matematika, dan observasi. Instrumen yang digunakan adalah soal tes prestasi belajar, angket sikap siswa terhadap matematika, dan lembar observasi. Analisis data dilakukan dengan analisis deskriptif kuantitatif. Hasil penelitian menunjukkan bahwa prestasi belajar dan sikap siswa terhadap matematika mengalami peningkatan setelah dilaksanakan tindakan melalui heuristic problem solving dalam menyelesaikan soal cerita matematika. Tes prestasi belajar sebelum tindakan adalah 59,5\%, kemudian meningkat $72,9 \%$ pada siklus I, dan meningkat lagi menjadi $91,8 \%$ pada siklus II. Hasil angket sikap siswa terhadap matematika juga mengalami peningkatan, dari 48,7 pada pra tindakan, meningkat menjadi 81,1 dengan kriteria positif pada siklus I dan meningkat lagi menjadi 86,5 dengan kriteria positif pada siklus II.

Kata kunci: heuristic problem solving, soal cerita, prestasi, sikap siswa.

Abstract

This study aim to improve student achievement and attitudes toward mathematics through heuristic problem solving to solve math story problems. This was a collaborative classroom action research (CAR). The research collaborator was the fourth grade math teacher as the action doer. The data were collected through student achievement test, questionnaire students attitudes toward mathematics, and observation. The instrument included student achievement test, questionnaire attitudes toward mathematics, and observation sheets. The data were analyzed by quantitative descriptive analysis. The results of the study showed that students' achievement and attitudes toward mathematics improved after the learning actions using the heuristic problem solving in solving mathematical word problems. Achievement test before the action was 59.5\%, and increased $72.9 \%$ in cycle I, and increased again to $91.8 \%$ in cycle II. Results of students' attitudes toward mathematics questionnaire also increased, from 48.7 on pre-action, increased to 81.1 with the positive criteria in cycle I and increased again to 86.5 with the positive criteria in cycle II.
\end{abstract}

Keywords : heuristic problem solving, student achievement, attitudes toward mathematics 


\section{Pendahuluan}

Pembelajaran matematika di Sekolah Dasar mempunyai kedudukan yang sangat penting dalam upaya untuk mewujudkan tujuan pengajaran matematika yang telah ditetapkan. Tujuan pengajaran matematika adalah untuk: 1) menumbuhkan dan mengembangkan keterampilan berhitung (menggunakan bilangan sebagai alat dalam kehidupan sehari-hari; 2) menumbuhkan kemampuan siswa, yang da-pat dialih gunakan melalui kegiatan matematika; 3) mengembangkan pengetahuan dasar matematika sebagai bekal belajar lebih lanjut di SMP; dan 4) membentuk sikap logis, kritis, cermat dan disiplin (Depdikbud 1994). Dengan demikian tujuan pembelajaran matematika tidak hanya dimaksudkan agar siswa terampil melakukan operasi penjumlahan, pengurangan, perkalian, dan pembagian, tetapi juga untuk mengusahakan agar siswa mampu menggunakan keterampilan tersebut untuk menyelesaikan masalah (problem solving).

Tujuan pembelajaran matematika adalah agar siswa mampu menggunakan keterampilan tersebut untuk menyelesaikan masalah (problem solving). Pembelajaran soal cerita (word/story problem) dapat digunakan sebagai wahana untuk melatih murid SD dalam menyelesaikan masalah. Untuk itu kurikulum matematika SD pada setiap akhir bab sering kali siswa dihadapkan pada soal cerita, dengan tujuan untuk melatih keterampilan siswa tersebut dalam menyelesaikan masalah matematika dengan kehidupan sehari-hari. Selain siswa mampu menyelesaikan masalah (problem solving), siswa juga diharapkan untuk mencapai kompetensi dan hasil belajar yang baik, perlu juga diimbangi dengan sikap positif terhadap matematika.

Tujuan pembelajaran matematika Sekolah Dasar dilaksanakan dengan berpedoman pada standar proses dan standar isi. Standar proses sebagaimana dimaksud dalam kurikulum mata pelajaran matematika Sekolah Dasar, mencakup kompetensi problem solving, penalaran dan pembuktian, komunikasi, koneksi dan penyajian materi. Sedangkan standar isi mencakup aritmetika (bilangan), geometri, pengukuran dan pengolahan data (Depdiknas, 2005, p.33). Berdasarkan standar isi, materi pecahan terdapat di dalam aritmetika. Materi pecahan dikenalkan atau diberikan sejak siswa berada di kelas III. Untuk operasi baik penjumlahan, pengurangan, perkalian, maupun pembagian dipelajari mulai dari kelas IV sampai kelas VI. Materi pecahan merupakan salah satu bahan ajar yang harus dikuasai oleh siswa Sekolah Dasar sejak dini. Namun siswa SD kelas rendah masih sulit membayangkan hal-hal yang abstrak sehingga guru sering menemukan siswa kelas atas tidak menguasai materi bilangan pecahan dengan baik. Sebagai contoh: Ani mempunyai pita panjangnya $\frac{1}{2}$ meter. Santi mempunyai pita panjangnya $\frac{1}{3}$ meter. Berapa meter jumlah panjang pita mereka? Siswa akan menjawab $\frac{1}{2}+\frac{1}{3}$ $=\frac{2}{5}$ (pembilang ditambah dengan pembilang dan penyebut ditambah dengan penyebut).

Hal serupa juga dialami juga dialami oleh siswa kelas IV SD Negeri I Mangkujayan Ponorogo dalam mengerjakan soal operasi pecahan mereka masih banyak yang melakukan dengan menjumlahkan pembilang dengan pembilang, penyebut dengan penyebut. Kesalahan konsep ini membuat anak merasa kesulitan dalam mempelajari matematika. Karena adanya kesalahan konsep ini, nilai anak dalam mengerjakan operasi bilangan pecahan banyak yang jelek.

Soal cerita dalam matematika sekolah diajarkan di setiap jenjang pendidikan. Soal cerita yang dipelajari di sekolah dasar selain sebagai bekal belajar lebih lanjut, juga bermanfaat bagi siswa dalam belajar memecahkan masalah dalam kehidupan sehari-hari. Tetapi kenyataan di lapangan topik yang dianggap sulit khususnya bagi siswa SD adalah soal cerita. Penyebabnya adalah kurangnya keterampilan siswa dalam menerjemahkan kalimat sehari-hari ke dalam kalimat matematika. Diduga hal ini terjadi karena siswa belum cukup memiliki gambaran yang jelas khususnya cara mengaitkan antara keadaan real/nyata yang mereka temukan sehari-hari dengan kalimat matematika yang sesuai. Mungkin pula hal itu terjadi karena siswa kurang terlibat aktif secara mental (aktif mendayagunakan pikirannya) dalam pemecahan masalah.

Hal serupa juga terjadi di SD Negeri I Mangkujayan Ponorogo, berdasarkan observasi awal kebanyakan siswa kelas IV mengalami kesulitan dalam menyelesaikan soal cerita. Adapun kesulitan siswa tersebut adalah kesulitan siswa dalam memahami soal cerita yaitu siswa masih bingung dan tidak bisa memilah apa yang diketahui, apa yang ditanyakan dan cara penyelesaian serta jawaban. Mereka 
sulit mencerna maksud dari soal, jangankan mengerjakan, maksud soalnya saja tidak dapat dimengerti. Di dalam mempelajari topik soal cerita, walaupun sudah berulang kali dijelaskan ternyata masih banyak siswa yang belum dapat mengerjakan dengan benar. Ini dapat dilihat dari rendahnya prestasi belajar siswa dalam mengerjakan soal cerita. Berdasarkan tes awal yang dilakukan, siswa diberi 5 soal cerita pecahan. Dari 37 siswa 22 siswa nilainya di bawah SKBM, yaitu 75 dan 15 siswa nilainya di atas 75 .

Kesulitan siswa yang lain dalam memecahkan soal matematika bentuk cerita yaitu kemampuan dalam menghitung. Siswa seringkali salah dalam menghitung suatu bentuk perkalian, pembagian, penjumlahan dan pengurangan. Ketika anak tahu bagaimana menyelesaikan soal cerita tersebut, namun dalam perhitungan anak masih banyak yang salah. Mereka hanya mengalikan atau mem-bagi angka-angka dalam soal, tanpa tahu mengapa bisa dikalikan ataupun dibagi. Hal ini terjadi karena kemampuan bernalar mereka kurang diperhatikan. Mereka hanya mendengar, mencatat, mengerjakan tugas yang diberikan, tanpa tahu bagaimana penyelesaian yang benar. Pembelajaran masih berpusat pada guru, siswa tidak terlibat aktif dalam kegiatan pembelajaran. Guru mengikuti alur memberi informasi, ceramah, latihan soal dan pemberian tugas. Selama pembelajaran berlangsung banyak siswa yang tidak memperhatikan guru menjelaskan. Mereka asyik bermain dengan temannya. Pembelajaran matematika yang seperti ini mengakibatkan siswa bekerja secara prosedural tanpa memahami konsep yang sebenarnya dan daya nalar serta kreatifitas siswa tidak berkembang.

Berdasarkan hasil wawancara terhadap beberapa siswa didapatkan mereka kebanyakan tidak menyukai pelajaran matematika. Sebagian siswa malas belajar matematika karena banyak hitungan, sehingga siswa tidak menyukai matematika. Penjelasan guru juga menyebutkan bahwa siswa malas belajar, sehingga PR anak yang mengerjakan orangtuanya. Siswa selalu tegang jika belajar matematika sehingga mereka sulit menyukai dan menguasai konsep dasar matematika, cara belajar matematika seperti yang tidak sesuai dengan karakteristik anak membentuk sikap negatif anak terhadap matematika. Ternyata memang tidak sedikit anak yang memiliki sikap tidak suka, takut, malas atau kesulitan dalam belajar matematika. Pada proses pembelajaran berlangsung masih saja ada anak-anak yang bercanda dengan temannya, menggambar di buku tulisnya, sibuk sendiri dan tidak memperhatikan guru. Selain itu saat proses pembelajaran berlangsung peserta didik lebih asyik dengan kegiatannya sendiri dibandingkan dengan memperhatikan pelajarannya, sehingga guru harus seringkali mengingatkan kepada siswa untuk memperhatikan pelajaran pada saat pembelajaran berlangsung. Hal ini menunjukkan bahwa sikap siswa terhadap matematika masih rendah.

Menurut Baroody (1992, pp.2-18) heuristic problem solving mempunyai 4 tahap yaitu:

Pertama, memahami masalah. Dalam tahap ini siswa diminta untuk memahami permasalahan yang diberikan dengan membaca soal dengan teliti kemudian guru membantu siswa dalam memahami masalah kemudian meminta siswa menjelaskan dengan kata-katanya sendiri, menentukan apa yang tidak diketahui dalam soal serta menentukan informasi lain yang dibutuhkan.

Kedua, menyusun rencana. Dalam tahap menyusun rencana dapat membantu siswa dalam menyusun bagaimana penyelesaian dari permasalahan tersebut atau menentukan solusinya. Guru membantu siswa dalam membuat gambar, memeriksa beberapa contoh dan mencari pola, mendata data dalam daftar, tabel atau grafik, menyederhanakan masalah, menceritakan masalah agar mudah dipahami, menuliskan kalimat matematikanya, mengingat kembali, menggunakan penalaran serta menebak dan mengecek. Selain menggunakan berbagai strategi juga memperhatikan dalam hal memahami masalah, melaksanakan rencana serta mengevaluasi.

Ketiga, melaksanakan rencana. Siswa harus memahami pentingnya setiap langkah perencanaan agar pelaksanaan rencana dapat berjalan dengan baik. Dalam hal ini guru membantu siswa untuk memutuskan apakah sebuah sudut pandang baru diperlukan, menentukan apakah semua informasi yang relevan telah digunakan, serta mempertimbangkan apakah ada cara lebih mudah untuk memecahkan masalah.

Keempat, melihat kembali/mengecek. Tahap ini merupakan refleksi jawaban dari permasalahan yang ada. Siswa harus mengecek jawaban dari permasalahan, adakah cara yang lebih mudah, serta apa ada solusi lain. Guru 
membantu siswa untuk menentukan apakah solusinya sudah tepat, menentukan apakah solusinya sudah menjawab dari pertanyaannya serta memutuskan apakah ada solusi lain.

Rangkaian aktivitas berpikir siswa dan perilaku siswa selama memecahkan masalah dapat dianalisa berdasarkan model Polya (dalam Gorman, 1974, p.299). Proses pemecahan masalah atau strategi pemecahan masalah disebut dengan heuristic. Tujuan dari heuristic adalah untuk mempelajari metode dan aturanaturan untuk memperoleh solusi masalah, sehingga memungkinkan pemecahan masalah untuk memperoleh pengertian secara sistematis dari struktur masalah tersebut melalui usahanya sendiri. Dengan adanya heuristic problem solving siswa akan merasa bertantang untuk menyelesaikan permasalahan yang ada, sehingga dengan tantangan dan pengalaman yang dimiliki siswa pembelajaran matematika menjadi menyenangkan dan bermakna. Dengan pembelajaran yang menyenangkan maka sikap siswa terhadap matematika menjadi lebih positif dan prestasi belajar akan meningkat dengan sendirinya. Akan tetapi, di SD Negeri 1 Mangkujayan Ponorogo guru belum pernah menggunakan heuristic problem solving dalam menyelesaikan soal cerita.

Menurut Abidia (1989, p.10), soal cerita adalah soal yang disajikan dalam bentuk cerita pendek. Cerita yang diungkapkan dapat merupakan masalah kehidupan sehari-hari atau masalah lainnya. Menurut Haji (1994, p.13), soal yang dapat digunakan untuk mengetahui kemampuan siswa dalam bidang matematika dapat berbentuk cerita dan soal bukan cerita/ soal hitungan. "Word problems require children to focus on the meaning of the arithmetic operation. To solve a word problem, a child needs to translate the situation into an arithmetic sentence (or sometimes more than one sentence) and then do the computation called for in that sentence. There is usually one right way to get the answer; there is always one right answer".( Marilyn Burns, 1992, p.15).

Douglas (1992, p.672) menyatakan prestasi dalam matematika sering digunakan sebagai indikator untuk mengetahui pengetahuan yang dimemiliki siswa. Tes matematika khusus prestasi telah dikritik karena didominasi oleh tingkat rendah, keterampilan dasar item yang diproduksi dengan mudah dalam format kertas dan pensil. meskipun ini dan kekurangan lainnya, tes prestasi telah menjadi sumber utama bukti untuk menyelidiki ine- quility dalam pendidikan kelompok beragam. Prestasi belajar matematika adalah tingkat penguasaan materi dan pencapaian standar kompetensi matematika setelah siswa mengalami kegiatan belajar matematika yang diukur dengan menggunakan test berupa seperangkat soal matematika yang menggambarkan materi belajar dan mencerminkan kompetensi dasar yang dituntut.

Sikap merupakan proses evaluasi yang sifatnya internal atau subjektif yang berlangsung dalam diri seseorang dan tidak dapat diamati secara langsung. Sikap dapat diketahui melalui pengetahuan, keyakinan, perasaan, dan kecenderungan tingkah laku seseorang terhadap objek sikap. Kedalaman sikap seseorang terhadap objek dapat diukur melalui pengetahuannya, perasaannya, dan bagaimana ia memperlakukan objek tersebut. Sikap adalah konsep yang dibentuk oleh tiga komponen, yaitu kognitif, afektif, dan perilaku. Komponen kognitif berisi semua pemikiran serta ide-ide yang berkenaan dengan objek sikap. Isi pemikiran seseorang meliputi hal-hal yang diketahui sekitar objek sikap, dapat berupa tanggapan atau keyakinan, kesan, atribusi, dan penilaian tentang objek sikap (Istiqomah Wibowo, 2009, p.83).

Hasil penelitian tentang implementasi pembelajaran melalui strategi problem solving dapat membantu siswa dalam meningkatkan prestasi, minat serta merubah sikap siswa terhadap pembelajaran. "The exposure to problem-solving strategies that students receive can help them improve their achievement, increase their interest in a subject, and change student attitudes towards learning". Gok dan Silay (dalam Ruhizan Yasin, 2012, p.66). Penelitian lain mengenai penerapan langkah-langkah pemecahan masalah dalam menyelesaikan soal cerita menunjukkan hasil: (1) pendekatan dengan menggunakan langkah-langkah pemecahan masalah dalam menyelesaikan soal cerita merupakan pendekatan yang dapat menghasilkan prestasi belajar yang lebih baik daripada cara biasa untuk siswa kelompok tinggi dan sedang, (2) untuk kelompok siswa yang berkemampuan rendah penggunaan langkah-langkah pemecahan masalah tidak berbeda dengan menggunakan cara biasa (Sahat Saragih, 1999, p.301). Kajian penelitian di atas, tentang implementasi strategi dan langkahlangkah problem solving dalam pembelajaran sedangkan penelitian ini mengenai implemen- 
tasi heuristic problem solving dalam menyelesaikan soal cerita matematika SD.

Penelitian ini dibatasi pada implementasi heuristic problem solving dalam menyelesaikan soal cerita matematika yang belum dilaksanakan di kelas dan pada prestasi belajar siswa yang masih rendah serta sikap siswa terhadap matematika yang masih rendah dimana siswa tidak menyukai pelajaran matematika karena dianggap sulit. Oleh karena itu, penelitian ini difokuskan pada upaya peningkatan prestasi belajar dan sikap siswa terhadap matematika melalui heuristic problem solving dalam menyelesaikan soal cerita matematika.

Rumusan masalah dalam penelitian ini adalah "bagaimanakah implementasi heuristic problem solving dalam menyelesaikan soal cerita matematika untuk meningkatkan prestasi belajar dan sikap siswa terhadap matematika?"

Tujuan utama penelitian ini adalah untuk meningkatkan prestasi belajar dan sikap siswa terhadap matematika melalui implementasi heuristic problem solving dalam menyelesaikan soal cerita matematika di SD.

\section{Metode}

Jenis Penelitian

Metode penelitian yang dilakukan dalam penelitian ini adalah Penelitian Tindakan Kelas (PTK) yang juga dikenal dengan Classroom Action Research (CAR). Bentuk PTK ini merupakan penelitian kolaboratif dimana guru dilibatkan sebagai tim yang melaksanakan tindakan. Model PTK yang digunakan dalam penelitian ini adalah model Kemmis \& Tanggart. Masing-masing siklus terdiri dari tahapan perencanaan, tindakan, observasi dan refleksi. Tujuan dari model Kemmis \& Tanggart adalah apabila pada awal pelaksanaan tindakan masih ditemukan adanya kekurangan maka dapat dilakukan perbaikan pada tindakan atau siklus selanjutnya sampai target yang diinginkan tercapai.

\section{Waktu dan Tempat Penelitian}

Penelitian ini dilaksanakan di SD Negeri 1 Mangkujayan Ponorogo. Penelitian dilaksanakan pada bulan Februari sampai dengan Mei 2012. Pemilihan lokasi penelitian ditentukan berdasarkan hasil dialog antara peneliti dengan guru mengenai permasalahan yang terjadi di kelas. Kemudian peneliti dan guru melaksanakan observasi awal dan menye- pakati untuk menindaklanjuti permasalahan tersebut.

Subjek penelitian ini adalah siswa kelas IV $_{\mathbf{A}}$ SD Negeri 1 Mangkujayan Ponorogo yang berjumlah 37 siswa, terdiri dari 18 siswa putra dan 19 siswa putri. Dalam penelitian ini melibatkan guru matematika kelas IV yaitu Bapak Ahmad Dahlan S.Pd sebagai pelaksana tindakan dan peneliti yaitu Ibu Dian Kristiana.

Guru dan peneliti mengidentifikasi permasalahan yang terjadi di kelas. Peneliti berperan sebagai perancang kegiatan pembelajaran. Peneliti merancang Rencana Pelaksanaan Pembelajaran (RPP), menyusun Lembar Permasalahan, dan berperan menjadi observer. Guru kolaborator sebagai pelaksana rancangan pembelajaran di kelas sekaligus sebagai observer.

\section{Desain Penelitian}

\section{Perencanaan}

Perencanaan adalah mengembangkan rencana tindakan untuk meningkatkan prestasi belajar dan sikap siswa terhadap matematika. Pada tahap ini dilakuakn langkah-langkah yang berupa: 1) Mengidentifikasi dan menetapkan permasalahan yang terjadi di kelas saat pembelajaran matematika, mengumpulkan data pendukung, merumuskan masalah dan menganalisisnya untuk menentukan hipotesis tindakan.; 2) Merancang RPP dan menyusun lembar permasalahan.; 3) Menyiapkan instrumen pengamatan aktivitas siswa dan guru.

\section{Pelaksanaan Tindakan}

Persiapan yang dilakukan pada siklus I antara lain: mempersiapkan RPP sebagai pedoman dalam pelaksanaan kegiatan pembelajaran, lembar observasi aktivitas siswa dan guru sabagi pedoman bagi observer dalam melaksanakan pengamatan pelaksanaan tindakan melalui heuristic problem solving dalam menyelesaikan soal cerita matematika.

\section{Observasi}

Observasi dilaksanakan untuk memonitor pelaksanaan tindakan secara berkelanjutan. Selama aktivitas pembelajaran berlangsung, peneliti dan peneliti sejawat melakukan pemantauan secara sistematis terhadap proses dan aktivitas belajar yang dilakukan guru dan siswa. 


\section{Refleksi}

Refleksi digunakan untuk melihat apakah proses tindakan pembelajaran yang dilakukan sudah memenuhi harapan atau tujuan yang telah ditetapkan sebelumnya. Pada PTK refleksi dilakukan berulang-ulang dan dilakukan pada setiap siklus. Melalui refleksi inilah rancangan siklus yang berikutnya disusun sehingga lebih baik dari pada siklus yang sebelumnya.

Data, Instrumen, dan Teknik Pengumpulan Data

Data yang dikumpulkan dalam penelitian ini yaitu: data tentang prestasi belajar siswa, sikap siswa terhadap matematika dan aktivitas siswa dan tindakan guru selama pembelajaran. Instrumen penelitian ini divalidasi oleh ahli, yang dalam penelitian ini dilakukan oleh Dr. Udik Budi Wibowo dan Dr. Suwarjo. Validasi oleh ahli atau praktisi ini bertujuan untuk memperoleh bukti validasi isi dan validasi konstruk instrumen. Setelah dikoreksi oleh validator, instrumen tersebut direvisi berdasarkan masukan dari validator.

Instrumen yang digunakan dalam penelitian ini yaitu:

Soal Tes

Soal tes digunakan untuk mengetahui peningkatan kemampuan prestasi belajar siswa setelah diadakan pembelajaran matematika dengan penerapan heuristic problem solving. Soal tes terdiri dari 5 soal cerita yang telah divalidasi oleh ahli atau tenaga profesional. Soal yang digunakan dalam penelitian ini bentuk soal cerita.

\section{Angket Sikap Siswa terhadap Matematika.}

Dalam penelitian ini angket yang digunakan untuk mendapatkan informasi mengenai sikap siswa terhadap matematika. Angket sikap terdiri dari 30 item yang telah divalidasi oleh ahli atau tenaga professional. Angket sikap siswa terhadap matematika berbentuk checklist menggunakan skala Linkert dengan 4 alternatif jawaban yaitu: sangat setuju, setuju, tidak setuju dan sangat tidak setuju. Skor masing-masing 4, 3, 2, dan 1 untuk pernyataan yang bersikap positif dan skor 1, 2, 3, dan 4 untuk pernyataan yang bersifat negatif.

\section{Lembar Observasi}

Kegiatan observasi dilakukan dengan pengamatan langsung oleh peneliti dan peneliti sejawat selama proses pembelajaran dilaksanakan. Observasi dilakukan kepada guru dan siswa melalui: lembar observasi terhadap aktivitas belajar siswa dan lembar observasi terhadap tindakan guru.

Tabel 1. Teknik Pengumpulan Data

\begin{tabular}{clll}
\hline No & $\begin{array}{c}\text { Sumber } \\
\text { Data }\end{array}$ & Jenis Data & \multicolumn{1}{c}{$\begin{array}{c}\text { Teknik } \\
\text { Pengumpulan } \\
\text { Data }\end{array}$} \\
\hline 1 & Siswa & Prestasi belajar & Tes \\
2 & Siswa & $\begin{array}{l}\text { Sikap siswa } \\
\text { terhadap } \\
\text { matematika } \\
\end{array}$ & $\begin{array}{l}\text { Lembar angket } \\
\text { sikap siswa }\end{array}$ \\
3 & Siswa & $\begin{array}{l}\text { Aktivitas siswa } \\
\text { dan tindakan guru } \\
\text { dan } \\
\text { guru }\end{array}$ & Observasi \\
& & pembelajaran & \\
\hline
\end{tabular}

Teknik Analisis Data

Penelitian tindakan ini menggunakan pendekatan kualitatif-kuantitatif. Sesuai dengan tujuan penelitian ini, teknik analisis data yang digunakan sebagai berikut:

\section{Analisis Tes Prestasi Belajar}

Tes prestasi belajar diukur dengan menggunakan instrumen soal tes yang berupa soal cerita matematika pokok bahasan operasi bilangan pecahan yang terdiri dari 5 soal. Skala penilaian yang digunakan adalah perseratus. Masing-masing soal bernilai 20, jika benar semua mendapatkan nilai 100. Berdasarkan ketuntasan belajar siswa maka dalam penelitian ini ditetapkan penerapan heuristic problem solving dalam menyelesaikan soal cerita dikatakan berhasil jika $80 \%$ siswa mempunyai nilai $\geq 75$ yaitu SKBM di SDN 1 Mangkujayan Ponorogo.

\section{Analisis Angket Sikap Siswa terhadap Mate- matika}

Sikap siswa terhadap matematika diukur dengan menggunakan instrument skala sikap yang akan dideskripsikan melalui analisis deskriptif. Data diperoleh dari pengukuran variabel sikap siswa terhadap matematika. Data yang diperoleh dihitung nilai rata-ratanya kemudian diinterpretasi ke dalam kriteriakriteria yang telah ditetapkan dan ditentukan rentang kriterianya.

Ketuntasan pada sikap siswa terhadap matematika ditentukan sesuai dengan kesepakatan peneliti dengan guru matematika kelas IV. Skor total bergerak dari skor terendah 30 (1 x 30) sampai dengan skor tertinggi $120(4 \mathrm{x}$ 
30). Untuk mendeskripsikan hasil pengukuran deskripsi sikap siswa terhadap matematika dilihat dari 5 kriteria sangat tinggi, tinggi, sedang, rendah, sangat rendah. Dilakukan dengan cara menentukan dahulu interval (i) sebagai berikut:

$$
\begin{aligned}
\mathrm{i} & =\frac{\text { banyak skor tertinggi-banyak skor terendah }}{\text { banyak kriteria }} \\
& =\frac{120-30}{5} \\
& =1,8
\end{aligned}
$$

Diperoleh interval

Tabel 2. Rentang Perolehan Skor dan Kriteria Penilaian

\begin{tabular}{cc}
\hline Rentang Perolehan Skor & Kriteria \\
\hline$X \geq 106$ & Sangat tinggi \\
$87 \leq x \leq 105$ & Tinggi \\
$68 \leq x \leq 86$ & Sedang \\
$49 \leq x \leq 67$ & Rendah \\
$30 \leq x \leq 48$ & Sangat rendah \\
\hline
\end{tabular}

Dari hasil skala angket ini akan diketahui bagaimana peningkatan intensitas sikap siswa terhadap matematika. Jika jumlah siswa dengan kriteria sikap tinggi dan sangat tinggi meningkat dan jumlah siswa dengan kriteria sikap sedang, rendah, sangat rendah menurun maka dapat dikatakan bahwa sikap siswa terhadap matematika semakin positif. Untuk keberhasilan peningkatan sikap siswa terhadap matematika berarti $80 \%$ siswa harus mencapai skor lebih dari 87 yaitu siswa yang memiliki sikap dengan kriteria tinggi atau sangat tinggi.

\section{Analisis Hasil Observasi}

Hasil observasi terhadap aktivitas siswa dan guru didapatkan dari data lembar checklist aktivitas siswa dan guru sehingga data yang diperoleh berupa data kualitatif yang akan dianalisis secara deskriptif kualitatif.

\section{Hasil Penelitian dan Pembahasan}

Deskripsi Data Hasil Penelitian Siklus I

\section{Rencana Tindakan}

Siklus I dilaksanakan dalam dua kali pertemuan. Selama pembelajaran berlangsung, peneliti mengadakan pengamatan dengan menggunakan lembar observasi yang telah disiapkan. Pada tindakan siklus I rencana pembelajaran bilangan pecahan di fokuskan pada pemecahan masalah sehari-hari yang melibatkan penjumlahan dan pengurangan bilangan pecahan. Materi pembelajaran pada siklus satu tindakan satu adalah soal cerita dengan pokok bahasan penjumlahan dan pengurangan pecahan. Proses dan materi yang diberikan dirancang atau dimodifikasi sesuai tujuan pembelajaran untuk meningkatkan prestasi belajar matematika serta sikap siswa terhadap matematika. Kompetensi dasar yang ingin dicapai dalam tindakan satu diadaptasi sesuai materi dan aspek-aspek peningkatan prestasi belajar matematika serta sikap siswa terhadap matematika. Sedangkan sumber materi merujuk pada buku pegangan guru yaitu buku pelajaran Ayo Belajar Matematika Untuk SD dan MI kelas IV, BSE serta Belajar Matematika untuk Sekolah Dasar Kelas 4, penerbit SIC.

\section{Pelaksanaan Tindakan}

\section{Pertemuan pertama}

Pada siklus I ini, pertemuan pertama tahap awal kegiatan berlangsung selama 10 menit. Guru memulai pembelajaran dengan mengucapkan salam, menanyakan kabar ke siswa. Untuk kegiatan apersepsi guru memotivasi siswa mengkaitkan pelajaran yang lalu dengan memberikan pertanyaan soal cerita pecahan. Kemudian guru memberikan permasalahan kepada siswa berupa lembar permasalahan yang berisikan dua soal cerita penjumlahan dan pengurangan pecahan. Guru meminta siswa untuk membaca permasalahan dan menekankan pentingnya membaca masalah dengan teliti.

Pada kegiatan inti yaitu pelaksanaan heuristic problem solving masing-masing siswa diberi lembar permasalahan oleh guru, dan diharapkan siswa dapat berdiskusi dengan teman sebangku. Guru mendampingi siswa dalam pelaksanaan heuristic problem solving yaitu memahami masalah, merencanakan tindakan, melaksanakan tindakan dan memeriksa jawaban.

Guru meminta salah satu siswa lakilaki untuk membaca soal no 1 , dan siswa yang lain disuruh untuk mendengarkan dan memperhatikan. Setelah itu guru bertanya kepada siswa apa yang diketahui dalam soal dan apa yang ditanyakan. Seluruh siswa menjawab pertanyaan dari guru yaitu ada kue yang dipotong menjadi 16. Emi makan 2 potong dan Sandra juga makan 2 potong. Sedangkan yang ditanyakan adalah bagian kue yang dimakan Emi dan Sandra serta kue yang tersisa. Dari uraian di atas siswa sudah mampu memahami masalah dengan baik mereka menggunakan kata-katanya sendiri untuk mengetahui mak- 
sud dari soal. Guru membantu siswa dalam memahami soal yang diberikan.

Untuk kegiatan merencanakan tindakan guru menanyakan kepada siswa langkah apa yang harus kalian kerjakan dari informasi tadi? Siswa diminta untuk menggambarkan kue ibu kemudian dipotong menjadi 16 lalu diambil 2 bagian dan 2 bagian lagi. Kemudian siswa mulai memikirkan dari gambar tadi langkah apa yang harus dilakukan untuk menyelesaikan masalah. Dari gambar yang telah mereka buat untuk menyelesaikan soal no 1a anak-anak mengarsir 2 bagian dari Emi dan 2 bagian dari Sandra. Baru setelah itu menuliskan kalimat matematikanya yaitu $\frac{2}{16}+\frac{2}{16}=\frac{4}{16}$. Siswa juga bertanya kepada pak Dahlan perlu disederhanakan apa tidak Pak? Melihat dari contoh yang diberikan sebelumnya biasanya sampai pada penyederhanaan. Begitu pula untuk menjawab yang $b$ mereka menggunakan gambar dan penalaran untuk menyelesaikan soal b. sisa kue yaitu $1-\frac{4}{16}=\frac{12}{16}$

Untuk soal no 2 guru juga meminta salah satu siswa perempuan untuk membacakan permasalahan soal no 2, siswa yang lain diminta untuk mendengarkan dan memperhatikan. Guru mengulangi membaca soal no 2 dan meminta siswa untuk memperhatikan. Kemudian guru meminta siswa untuk menjawab apa saja yang ada dalam soal? Apa yang ditanyakan? Siswa menjawab pertanyaan dari guru. Kemudian pak Dahlan meminta siswa untuk menuliskan langkah apa yang akan mereka tempuh? Guru juga mengingatkan ke siswa agar memeriksa contoh yang sudah diberikan sebelumnya. Kemudian anak mulai melihat dan memeriksa. Kebanyakan siswa menjawab aku tau caranya! Namun ada beberapa siswa yang masih bingung harus diapakan, dengan setia pak Dahlan membantu siswa untuk merencanakan langkah apa yang harus dilakukan. Mereka diminta agar menyederhanakan masalah agar lebih mudah dipahami. Setelah siswa mengetahui langkah apa yang ditempuh baru mereka menyelesaikannya. Guru bertanya kepada siswa "semua angkanya sudah dimasukkan? Dibaca lagi jangan sampai ada yang lupa". Setelah berkeliling pak Dahlan juga bertanya ada cara yang lebih mudah apa tidak? Kalau ada silahkan kalian gunakan. Ada beberapa siswa yang bertanya "boleh ya Pak pakai cara praktis?" iya silahkan terutama untuk mencari KPK. Setelah berputar-putar melihat pekerjaan siswa pak Dahlan kemudian berta- nya "sudah selesai anak-anak?, kalau sudah selesai jangan lupa diteliti kembali." Siswa menjawab "sudah selesai dan sudah diteliti". Pak Dahlan memotivasi siswa nanti yang dapat nilai 100 silahkan menulis bintang prestasinya. Setelah guru membantu siswa kemudian siswa diminta untuk maju mengerjakan lembar permasalahan di papan tulis untuk dibahas bersama-sama.

\section{Pertemuan kedua}

Pada pertemuan kedua tahap awal kegiatan berlangsung selama 15 menit. Guru memulai pembelajaran dengan mengucapkan salam, serta menanyakan siapa yang tidak masuk. Selain itu guru juga membagi siswa menjadi 8 kelompok yang terdiri dari 4 sampai 5 siswa. Guru menjelaskan aturan yang harus dilakukan oleh masing-masing kelompok. Kemudian memberikan lembar permasalahan kepada masing-masing kelompok. Lembar permasalahan terdiri dari 3 soal yaitu tentang penjumlahan dan pengurangan pecahan.

Pada kegiatan inti yaitu pelaksanaan heuristik problem solving masing-masing kelompok diberi lembar permasalahan oleh guru, dan diharapkan siswa dapat berdiskusi dengan teman sekelompoknya. Guru mendampingi siswa dalam pelaksanaan heuristic problem solving yaitu memahami masalah, merencanakan tindakan, melaksanakan tindakan dan memeriksa jawaban.

Masing-masing kelompok mengerjakan lembar permasalahan yang diberikan oleh guru. Pak Dahlan tidak bosan-bosannya mengingatkan ke siswa untuk membaca soal dengan teliti. Masing-masing kelompok memahami masalah yang ada dalam lembar permasalahan. Mereka mencatat apa yang diketahui serta apa yang ditanyakan dalam soal. Guru membimbing untuk memahami soal yang ada dalam lembar permasalahan. Dalam pembimbingan ke masing-masing kelompok guru meminta siswa untuk menjelaskan dengan kata-katanya sendiri agar siswa lebih mudah memahaminya. Selain itu juga mengingatkan langkah apa yang harus dilakukan. Siswa secara berkelompok berdiskusi untuk merencanakan langkah apa yang harus dilakukan untuk menyelesaikan 3 soal yang ada dalam lembar permasalahan.

Masing-masing kelompok mempunyai cara yang berbeda-beda untuk menyelesaikan permasalahan yang ada. Ada yang membuat gambar, ada yang melihat contoh yang sudah diberikan sebelumnya. Untuk penyelesaian 
soal no 1 dari 8 kelompok ada 6 kelompok yang benar. Mereka menggunakan gambar serta menyederhanakan masalah untuk menyelesaikannya. Setelah mereka menggunakan gambar baru menuliskan kalimat matematikanya serta menggunakan penalaran untuk menyelesaikan permasalahan. Setelah mereka menganggap bahwa cara yang mereka gunakan benar baru menyelesaikan soal. Guru mendampingi siswa dalam merencanakan tindakan, Pak Dahlan selalu membantu siswa yang belum bisa merencanakan langkah apa yang harus dilakukan untuk menyelesaikan soal. Selain itu guru juga selalu bertanya apa iya cara yang kalian ambil itu benar? selain itu juga memberi masukan ada cara yang mudah untuk menyelesaikan permasalahan itu. Pak Dahlan juga tidak berhenti untuk mengingatkan ke siswa agar membaca serta memahami maksud dari soal.

Untuk soal no 2 dari 8 kelompok semuanya menjawab dengan benar. mereka ingat contoh yang sudah diberikan oleh Pak Dahlan pada materi sebelumnya selain itu mereka dengan mudah memahami soal, sehingga dengan penalaran mereka dapat menyelesaikan soal no 2. Untuk soal no 3 mereka ada yang menggunakan gambar serta mendata apa yang harus dikerjakan. Sebidang tanah mereka gambarkan kemudian mereka mendata apa saja yang ada dalam permasalahan. Dengan bahasa dan gambar mereka bisa memahami maksud soal baru setelah itu menuliskan kalimat matematikanya dan kemudian dikerjakan. Pak Dahlan selalu berkeliling dan setia mendampingi siswanya dalam menyelesaikan lembar permasalahan yang diberikan. Setelah guru membantu siswa kemudian masing-masing kelompok diminta untuk maju mengerjakan lembar permasalahan di papan tulis untuk dibahas bersama-sama.

\section{Observasi}

Hasil observasi aktivitas siswa saat pembelajaran melalui heuristic problem solving, pada pertemuan pertama siswa sudah membaca soal dengan teliti ini dibuktikan dengan semua siswa bisa memahami permasalahan yang diberikan oleh guru. Semua siswa bisa memahami masalah dan menjelaskan dengan kata-katanya sendiri, sudah bisa menentukan apa yang tidak diketahui dalam soal, apa yang ditanyakan serta apa saja yang dibutuhkan untuk mengerjakan permasalahan. Dalam menyusun rencana mereka memperhati- kan petunjuk yang diberikan oleh guru sehingga mereka bisa menyusun serta melaksanakan rencana yang telah disusun. Untuk kegiatan memeriksa jawaban/melihat kembali sebagian anak belum memeriksa hanya sebagian saja yang memeriksa jawaban. Yang belum memeriksa jawaban hanya beberapa orang saja dan itu termasuk anak yang malas di kelas. Sedangakan pertemuan kedua siswa lebih antusias dalam membaca soal dan memahami soal. Dalam menyusun rencana mereka memperhatikan petunjuk yang diberikan oleh guru serta dari hasil diskusi kelompok sehingga mereka bisa menyusun serta melaksanakan rencana yang telah disusun. Untuk kegiatan memeriksa jawaban/melihat kembali anak sudah memeriksa pekerjaan mereka, meskipun dikerjakan secara berkelompok mereka secara bergantian memeriksa hasil pekerjaan mereka.

Dari hasil observasi tentang tindakan guru yaitu, guru sudah melaksanakan heuristic problem solving dengan baik, namun belum maksimal. Pada tahap memahami masalah guru sudah sangat membantu siswa dalam memahami permasalahan yang ada. Tahap perencanaan guru selalu mengarahkan dan membimbing siswa untuk merencanakan solusi yang tepat untuk permasalahan yang ada. Pada tahap melaksanakan rencana guru selalu berkeliling untuk melihat pekerjaan siswa sudah sesuai apa belum. Pada tahap memeriksa kembali guru sebenarnya sudah mengingatkan ke siswa, akan tetapi guru belum mengarahkan ke siswa apa ada solusi lain dari permasalahan yang ada.

\section{Refleksi}

Data yang diperoleh dari hasil observasi kemudian dianalisa dan dilakukan refleksi. Refleksi dilakukan antara peneliti dan guru yang bertujuan mengevaluasi tindakan yang telah dilakukan. Hasil refleksi peneliti dan guru pada siklus pertama adalah sebagai berikut:

Pada pertemuan awal siklus I siswa masih kesulitan dalam merencanakan tindakan, sebagian siswa masih merasa bingung dalam memahami soal. Bahasa yang digunakan dalam soal tidak mudah dipahami oleh anak.

Pada pertemuan kedua siswa kurang teliti dalam tahap evaluasi, kebanyakan siswa mengalami kesalahan dalam operasi penjumlahan maupun pengurangan.

Mereka malas untuk memeriksa lagi, ketika belum terbiasa untuk memeriksa kembali jawaban mereka. Biasanya hanya dilihat 
apakah sudah ada jawabannya apa belum tanpa memikirkan apa ada cara yang lebih mudah sehingga nanti akan dikoreksi apakah jawabannya sama.

Pada kegiatan diskusi kelompok untuk menyelesaikan permasalahan pada pertemuan kedua siklus I belum berjalan maksimal. Karena jumlah siswa dalam satu kelompok yang terdiri dari 4 sampai 5 siswa belum bekerja secara maksimal. Tidak semua siswa dalam satu kelompok mengerjakan, hanya 2 sampai 3 anak saja. Akan tetapi ada beberapa kelompok yang sungguh-sungguh bekerja bersama-sama.

Untuk mengatasi kekurangan pada siklus I, guru akan memperbaiki proses pembelajarannya pada siklus II. Pembelajaran pada siklus II dirancang dengan mempertimbangkan beberapa pertimbangan berikut; 1) Lembar permasalahan disusun menggunakan bahasa yang lebih mudah dipahami oleh siswa.; 2) Pada tahap evaluasi guru akan lebih intensif dalam membimbing siswa untuk memeriksa jawaban serta mengevaluasi jawaban.; 3) Proses diskusi kelompok lebih dimaksimalkan dengan mengurangi jumlah siswa dalam masingmasing kelompok, sehingga semua siswa terlibat dalam proses penye-lesaian masalah.; 4) Guru akan lebih intensif lagi dalam membimbing siswa untuk menerapkan heuristic problem solving.

\section{Deskripsi Data Hasil Penelitian Siklus II}

\section{Rencana Tindakan}

Pada siklus II tindakan yang dilaksanakan pada prinsipnya sama dengan siklus I. Materi pembelajaran pada siklus dua adalah soal cerita dengan pokok bahasan penjumlahan dan pengurangan pecahan. Proses dan materi yang diberikan dirancang atau dimodifikasi sesuai tujuan pembelajaran untuk meningkatkan prestasi belajar matematika serta sikap siswa terhadap matematika. Kompetensi dasar yang ingin dicapai dalam tindakan satu diadaptasi sesuai materi dan aspek-aspek peningkatan prestasi belajar matematika serta sikap siswa terhadap matematika. Sedangkan sumber materi merujuk pada buku pegangan guru yaitu buku pelajaran Ayo Belajar Matematika untuk SD dan MI kelas IV, BSE serta Belajar Matematika untuk Sekolah Dasar Kelas 4, penerbit SIC.

Langkah pembelajaran disusun sesuai dengan ketentuan heuristic problem solving, yaitu: memahami masalah, menyusun rencana, melaksanakan rencana serta memeriksa jawaban/melihat kembali. Selain itu pembelajaran pada siklus dua ini dirancang secara berkelompok. Merujuk dari siklus pertama jika terdiri dari 4-5 siswa kurang efektif maka dipersempit menjadi 3-4 siswa sehingga lebih maksimal. Pembagian kelompok dimaksudkan untuk menggalang minat belajar siswa serta keaktifan siswa dalam belajar. Selain itu dengan berkelompok, siswa yang belum bisa akan mendapat pengetahuan dari teman kelompoknya, serta mempermudah guru dalam memberikan bantuan ke siswa.

\section{Pelaksanaan Tindakan}

Pada siklus II ini, tahap awal kegiatan berlangsung selama 15 menit. Guru memulai pembelajaran dengan mengucapkan salam, membagi siswa menjadi 10 kelompok yang terdiri dari 3 sampai 4 siswa. kemudian memberikan permasalahan kepada siswa serta meminta siswa untuk membaca permasalahan dan menekankan pentingnya membaca masalah dengan teliti. Guru memberikan permasalahan tentang soal cerita pecahan yang berjumlah 5 soal. Selain itu guru juga memotivasi siswa dengan tebak-tebakan soal.

Pada kegiatan inti yaitu pelaksanaan heuristic problem solving masing-masing siswa diberi lembar permasalahan oleh guru, dan diharapkan siswa dapat berdiskusi dengan teman sekelompoknya. Guru mendampingi siswa dalam pelaksanaan heuristic Problem solving yaitu memahami masalah, merencanakan tindakan, melaksanakan tindakan dan memeriksa jawaban.

Dalam kegiatan memahami masalah guru membantu siswa untuk memahami masalah kemudian meminta siswa menjelaskan dengan kata-katanya sendiri, menentukan apa yang tidak diketahui dalam soal serta membantu jika ada informasi yang dibutuhkan. Masing-masing kelompok sudah bisa memahami permasalahan yang diberikan.

Kegiatan merencanakan tindakan guru membantu siswa untuk merencanakan tindakan yang sesuai dengan permasalahan yang diberikan. Guru membimbing siswa secara intensif pada masing-masing kelompok, menanyakan kepada mereka apa yang harus kalian lakukan untuk menyelesaikan permasalahan itu. Mereka berlomba-lomba untuk bertanya jika mereka belum mengerti.

Kegiatan pelaksanaan rencana guru membantu siswa untuk melaksanakan rencana 
yang telah disusun. Selain itu juga mengingatkan siswa dengan bertanya "apakah ada cara yang lain yang lebih mudah?" Guru juga mengingatkan untuk selalu membaca kembali permasalahan yang diberikan. Pak Dahlan pun juga tidak bosan-bosannya bertanya "apakah cara yang kalian pakai sudah sesuai dengan maksud soal?" berikut gambar penjelasan pak Dahlan ke siswanya agar menyelesaikan permasalahan sesuai dengan perencanaan siswa. Untuk kegiatan memeriksa jawaban/melihat kembali guru membantu siswa untuk menentukan apakah solusinya sudah tepat, sudah menjawab dari pertanyaannya, serta memutuskan apa ada solusi lain. Guru memotivasi siswa untuk memeriksa jawaban dengan memberikan penghargaan kepada kelompok yang dapat menjawab dengan benar. Setelah guru membantu siswa kemudian siswa diminta untuk maju mengerjakan lembar permasalahan di papan tulis untuk dibahas bersama-sama.

Pada kegiatan penutup, guru mendorong siswa untuk mengevaluasi jawaban. Guru memberikan solusi jawaban. Karena ada berbagai cara yang dikerjakan siswa dalam mengerjakan permasalahan.

\section{Observasi}

Siswa sangat antusias dalam membaca soal dengan teliti ini dibuktikan dengan semua siswa bisa memahami permasalahan yang diberikan oleh guru. Semua siswa bisa memahami masalah dan menjelaskan dengan katakatanya sendiri, sudah bisa menentukan apa yang tidak diketahui dalam soal, apa yang ditanyakan serta apa saja yang dibutuhkan untuk mengerjakan permasalahan. Dalam menyusun rencana mereka memperhatikan petunjuk yang diberikan oleh guru serta dari hasil diskusi kelompok sehingga mereka bisa menyusun serta melaksanakan rencana yang telah disusun. Untuk kegiatan memeriksa jawaban/melihat kembali anak sudah memeriksa pekerjaan mereka, meskipun dikerjakan secara berkelompok mereka secara bergantian memeriksa hasil pekerjaan mereka. Siswa sangat antusias dalam proses pembelajaran berlangsung, mereka merasa senang dengan pembelajaran yang diterapkan.

Dari hasil observasi tentang tindakan guru yaitu, guru sudah melaksanakan heuristic problem solving dengan baik. Pada tahap memahami masalah guru sudah sangat membantu siswa dalam memahami permasalahan yang ada. Tahap perencanaan guru selalu mengarah- kan dan membimbing siswa untuk merencanakan solusi yang tepat untuk permasalahan yang ada. Pada tahap melaksanakan rencana guru selalu berkeliling untuk melihat pekerja-an siswa sudah sesuai apa belum. Pada tahap memeriksa kembali guru tidak bosan-bosannya mengingatkan ke siswa sambil memotivasi siswa dengan pemberian bintang prestasi jika siswa memeriksa jawaban serta menemukan solusi lain sampai siswa bisa berpikir ternyata ada cara lain.

\section{Refleksi}

Setelah dilaksanakan tindakan pada siklus II, sikap siswa terhadap matematika telah mengalami peningkatan. skor sikap siswa terhadap matematika pada siklus II rata-rata adalah sangat positif. Pada siklus I rata-rata skor sikap siswa adalah 81,1 dengan kriteria positif dan meningkat menjadi 86,5 dengan kriteria sangat positif pada siklus II.

Meningkatnya sikap siswa terhadap matematika juga membawa peningkatan pada prestasi belajar siswa. Prestasi belajar siswa juga mengalami peningkatan. Hal ini ditunjukkan dengan skor prestasi belajar matematika siswa pada siklus I rata-rata kelas nilai siswa adalah 85,9 dengan prosentase ketuntasan belajar secara klasikal sebesar 75,6\%. Pada siklus II rata-rata nilai siswa adalah 93,2 dengan prosentase ketuntasan belajar sebesar 91,8\%. Sehingga prestasi belajar siswa mengalami peningkatan.

Berdasarkan data hasil tes prestasi belajar dan angket sikap siswa terhadap matematika pada siklus II ini prestasi belajar dan sikap siswa terhadap matematika telah mengalami peningkatan sesuai dengan target yang telah ditetapkan. Oleh karena itu, penelitian ini diakhiri pada siklus II.

Analisis Hasil Penelitian

Analisis Hasil Tes Prestasi Belajar Matematika

Tabel 3. Peningkatan Hasil Tes Prestasi Belajar Matematika.

\begin{tabular}{ccccc}
\hline Siklus & $\begin{array}{c}\text { Nilai } \\
\text { Rata- } \\
\text { rata }\end{array}$ & $\begin{array}{c}\text { Siswa } \\
\text { Tuntas } \\
\text { belajar }\end{array}$ & $\begin{array}{c}\text { Siswa } \\
\text { Belum } \\
\text { Tuntas } \\
\text { Belajar }\end{array}$ & $\begin{array}{c}\text { Ketuntasan } \\
\text { Belajar } \\
(\%)\end{array}$ \\
\hline Pra & 55,7 & 15 & 22 & 40,5 \\
Siklus & 27 & 10 & 72,9 \\
I & 87,0 & 27 & 3 & 91,8 \\
II & 93,5 & 34 & &
\end{tabular}


Tabel 3 menyajikan data mengenai peningkatan prestasi belajar siswa dari sebelum tindakan sampai setelah dilaksanakan tindakan.

\section{Analisis Sikap Siswa terhadap Matematika}

Berikut ini adalah peningkatan sikap siswa terhadap matematika dari sebelum tindakan sampai setelah dilaksanakan tindakan dalam persen.

Tabel 4. Peningkatan Kriteria Sikap Siswa terhadap Matematika (dalam \%)

\begin{tabular}{|c|c|c|c|c|}
\hline No & Kriteria & $\begin{array}{c}\text { Pra } \\
\text { Siklus }\end{array}$ & $\begin{array}{c}\text { Siklus } \\
\text { I }\end{array}$ & $\begin{array}{c}\text { Siklus } \\
\text { II }\end{array}$ \\
\hline 1 & Sangat Tinggi & 2,7 & 13,5 & 24,3 \\
\hline 2 & Tinggi & 46,0 & 67,6 & 62,2 \\
\hline 3 & Sedang & 40,5 & 18,9 & 13,5 \\
\hline 4 & Rendah & 10,8 & 0 & 0 \\
\hline 5 & Sangat Rendah & 0 & 0 & 0 \\
\hline
\end{tabular}

Pembahasan

Setelah dilakukan tindakan dengan menerapkan heuristic problem solving untuk menyelesaikan soal cerita matematika operasi hitung bilangan pecahan terjadi peningkatan rata-rata nilai prestasi belajar siswa 85,9 dengan persentase klasikal 75,6\%. Karena belum memenuhi target yang diinginkan maka dilaksanakan tindakan berikutnya pada siklus II. Tindakan yang dilakukan pada siklus II yaitu implementasi heuristic problem solving dengan kerja kelompok. Setelah dilaksanakan tindakan tindakan pada siklus II rata-rata nilai prestasi belajar siswa meningkat menjadi 93,2 dengan persentase klasikal sebesar 91,8\%.

Hasil penelitian ini menunjukkan bahwa implementasi heuristic problem solving dapat meningkatkan prestasi belajar siswa. Dengan adanya peningkatan sikap siswa terhadap matematika juga akan berpengaruh pada peningkatan prestasi belajar siswa.

Meningkatnya sikap siswa terhadap matematika bisa dilihat dari hasil angket sikap siswa terhadap matematika sebelum dilaksanakan tindakan hanya 48,7\% siswa dengan kriteria tinggi dan sangat tinggi. Setelah dilaksanakan tindakan dengan heuristic problem soving pada siklus I meningkat menjadi $67,6 \%$ sikap siswa menunjukkan kategori tinggi dan 13,5\% menunjukkan kategori sangat tinggi. Pada siklus II terjadi peningkatan cukup signifikan yaitu ada 24,3\% dengan kriteria sangat tinggi dan $62,2 \%$ dengan kriteria tinggi. Artinya hampir seluruh siswa sudah menyukai pelajaran matematika dan menganggap matematika tidak sulit lagi. Dari data ini bisa disimpulkan bahwa sikap siswa terhadap matematika meningkat setelah dilaksanakan heuristic problem solving dalam menyelesaikan soal cerita matematika.

\section{Simpulan dan Saran}

Simpulan

Implementasi heuristik Problem Solving dalam menyelesaikan soal cerita matematika dapat meningkatkan prestasi belajar matematika siswa kelas IV SDN Mangkujayan I Ponorogo. Hal tersebut terlihat dari adanya peningkatan skor rata-rata tes hasil belajar yang lebih baik jika dibandingkan dengan sebelum pelaksanaan tindakan, yaitu nilai rata-rata kelas pada siklus I adalah 87,03. Pada siklus II nilai rata-rata meningkat menjadi 93,5 . Ketuntasan belajar secara klasikal siswa meningkat, pada siklus I ketuntasan secara klasikalnya adalah $72,9 \%$ dan pada siklus II mencapai $91,8 \%$.

Impementasi heuristik Problem Solving dalam menyelesaikan soal cerita matematika dapat meningkatkan sikap siswa terhadap matematika kelas IV SDN Mangkujayan I Ponorogo. Hasil penelitian menunjukkan bahwa sikap siswa terhadap matematika mengalami peningkatan yang sangat positif. Pada siklus I rata-rata skor sikap siswa adalah 81,1 dengan kriteria tinggi dan meningkat menjadi 86,5 dengan kriteria sangat tinggi pada siklus II.

\section{Keterbatasan Penelitian}

Adapun keterbatasan penelitian ini adalah Pelaksanaan tindakan hanya dilakukan pada sela-sela sebelum pelaksanaan ulangan sub sehingga peningkatan prestasi belajar dan sikap siswa terhadap matematika belum optimal. Pelaksanaan tindakan ini hanya dilakukan satu kompetensi dasar yaitu menyelesaikan masalah yang berkaitan dengan pecahan.

Saran

Berdasarkan hasil dan temuan yang diperoleh serta dengan memperhatikan keterbatasan penelitian, saran yang disampaikan adalah sebagai berikut:

Penerapan heuristic problem solving dalam menyelesaikan soal cerita melalui penelitian ini telah berhasil dalam meningkatkan prestasi belajar dan sikap siswa terhadap matematika pada pokok bahasan operasi bilangan 
pecahan. Guru pada mata pelajaran matematika disarankan untuk menerapkan heuristic problem solving ini sebagai alternatif dalam pembelajaran matematika.

Guru dapat menerapkan heuristic problem solving untuk menyelesaikan soal cerita matematika tidak hanya materi pecahan, namun juga materi yang lain karena dapat meningkatkan prestasi belajar dan sikap siswa terhadap matematika.

Guru dalam menerapkan heuristic problem solving perlu memberikan variasi pembelajaran kelompok secara bergantian sesuai dengan kebutuhan, serta pemberian variasi soal cerita matematika perlu ditingkatkan supaya siswa terbiasa berpikir kritis dan mampu menyelesaikan masalah dengan pemikiran mereka.

Penerapan heuristic problem solving selain dapat meningkatkan prestasi belajar dan sikap siswa terhadap matematika, juga dapat dikembangkan untuk meningkatkan atau mewujudkan aspek yang lain yaitu motivasi dan hasil belajar sehingga disarankan perlu adanya penelitian lanjutan untuk meningkatkan aspek yang lain.

\section{Daftar Pustaka}

Baroody, A.J. (1993) Problem solving, reasoning, and communicating, $K-8$ : helping children think mathematically. Englewood Cliffs, NJ: Macmillan Publishing Company.
Burn, M (1992). About teaching mathematics A $K-8$ resource. Sausalito, CA: Math Solutions Publication

Douglas, A.G. (1992). Handbook of research on mathematics teaching and learning: A project of the national council of teacher of mathematics. New York: Macmillan Publishing Company

Gorman, R.M (1974). The psychology of classroom learning: An inductive approach. Columbus: Bell and Howell Company

Saragih, Sahat (1999). Penerapan Langkahlangkah Pemecahan Masalah dalam Menyelesaikan Soal Cerita [versi electronik]. Jurnal Penelitian Bidang Pendidikan vol 6 no 1

Wibowo, Istiqomah. (2009). Sikap. dalam Sarwono, S.W., Meinarno, E.A. Psikologi Sosial. Jakarta: Salemba Himonika.

Yasin, Ruhizan (2012). Effects of Problemsolving Strategies in the Teaching and Learning of Engineering Drawing Subject [versi electronic]. Journal Asian Social Science; Vol. 8, No. 16. 